\section{Allergy Immunology}

\title{
In Memoriam - A Tribute to Alain L. de Weck
}

Professor Alain L. de Weck passed away on April 8, 2013 , at the age of 84 , and we have lost one of the great characters in International Allergology of the second half of the 20th century.

Alain de Weck was born in 1928 in Les Avants northeast of the town of Montreux. His father was a practicing pneumologist in the Swiss mountains. There, he got early impressions on medical treatment. He then studied medicine in Fribourg, Lausanne and Geneva and became a resident at the Dermatology Department in Geneva with Prof. Werner Jadassohn. Already at that time he had developed profound interests in immunology trying to study mechanisms of contact dermatitis; immunology as a discipline hardly existed in those days. From 1958 to 1960, Alain de Weck worked in the laboratory of Herman Eisen at Washington University School of Medicine in St. Louis, Miss., USA, where he was particularly interested in studying the interaction of small molecules - in particular penicillins - with proteins. Alain de Weck was always keen to apply scientific basic knowledge to clinical practice. Through his work, it became clear that low molecular weight monovalent haptens are not able to elicit allergic immediate-type reactions such as histamine release from mast cells but that bridging of at least two or several binding sites is mandatory.

Coming back from the USA in 1961, he built up a division of allergy research at the University of Bern which finally became the Institute of Allergy and Clinical Immunology and which he lead until his retirement in 1993. During his leadership, this rather small institute became

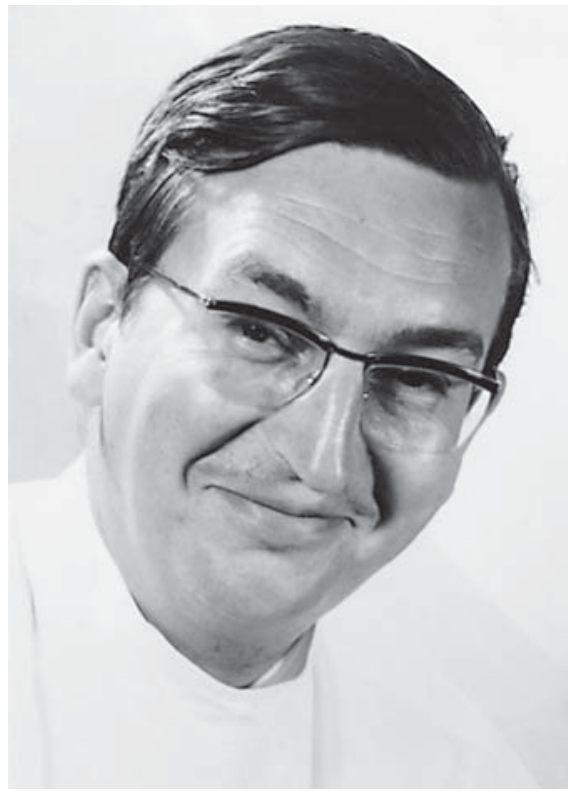

Prof. Dr. Alain L. de Weck, 1928-2013

widely known for its allergy research and attracted many scientists from all over the world. He was engaged in various projects such as developing better diagnostic techniques with in vitro cellular assays and the sulfidoleukotriene release from basophils after priming with interleukin 3, aspects of T-cell regulation, $\operatorname{IgE}$ and anti-IgE antibodies as well as drug allergy. In 1990, he started the European Network of Drug Allergy, which became an

\section{KARGER}

E-Mail karger@karger.com www.karger.com/iaa
(C) 2013 S. Karger AG, Basel

1018-2438/13/1621-0097\$38.00/0 
important interest group to promote clinical and basic science in the field of drug allergy and has been active ever since under the umbrella of the European Academy of Allergy and Clinical Immunology. Besides his scientific activities, Alain de Weck devoted much time to the promotion of allergy and allergy research on a global level. He was a member in an endless list of committees and board of directors of national and international societies; he was an incessant advocate for the field of allergy. Thanks to him, the standing of allergy as a discipline improved and allergy research was put on the agenda in many countries. Thereby, his talent for languages (he spoke French, German and English daily, occasionally Italian and Spanish) and his clever and thoughtful formulations were a big asset.

His remarkable talent of integration was of great benefit for several scientific societies; he was probably the only person in the history of allergy and immunology who - both and partly at the same time - was president of the International Union of Immunology Societies (1983-1986) and the International Association of Allergology and Clinical Immunology (IAACI; 19851988).

His favorite among the international allergy communities, however, was the Collegium Internationale Allergologicum (CIA), where over decades he was honorary secretary and finally president and - in succession of Paul Kallos - the spiritus rector and motor of this collegium.

He was actively involved in the organization of several symposia of this collegium, the last one in 1980 in Konstanz.

On a broader level, it was the organization of the International Congress of Allergology and Clinical Immunology in 1988 in Montreux which remains unforgettable for the participants. He changed the IAACI profoundly by introducing task forces and working groups such as the Allergen Nomenclature Group together with the International Union of Immunology Societies under the umbrella of the WHO.

As founding editor of the journal Allergy and Clinical Immunology News (later Allergy and Clinical Immunology International), the official organ of the IAACI, now the World Allergy Organization, he managed to bring difficult concepts of modern and basic immunology in an understandable language to practicing allergists all over the world.

Alain de Weck received many national and international awards, among them the Robert Koch Award in 1973 and the Karl-Hansen Medal in 1993.
Alain de Weck worked hard to achieve his international reputation - and he liked to work. Research was his passion: he was not satisfied with clinical observations alone but always tried to understand the mechanisms behind the processes and looked for applications of his research in practice. He always insisted on the connection between immunology and allergy and considered allergy and allergy research as part of immunology. He was curious and original and brought new ideas to discussions and then to experiments. His coworkers at the institute in Bern found some of his ideas quite audacious, but he was never offended when they did not agree immediately. Alain de Weck was honest, self-critical and could laugh a lot about himself with a very astute sense of humor. $\mathrm{He}$ knew about the weaknesses and vanity of people and bore the envy of some colleagues stoically. He was able to motivate young researchers and supported young allergists from all over the world. His pupils were highly motivated by his enthusiasm, honesty and friendship and his obvious joy when they were successful.

Alain de Weck was married three times and in his excellent and very recommendable memoirs Notes of an Allergy-Watcher - Memories: Failures and Dreams which appeared in 2008, he not only wrote about his professional life and academic achievements but also dared to give 'inner court' reflections on the important matters of life regarding men and women. People who knew him well could learn a lot from him, much more than allergy and immunology!

Alain de Weck leaves behind his wife Brigitte and his children Lionel, Carola, Christoph and Olivier with their wives and husband and 8 grandchildren, who were present at the funeral ceremony in the beautiful cathedral of Fribourg on Friday April 12, 2013.

Although he had been in a wheel chair for the last two years of his life, he was mentally very active and participated in the life of the allergy community. Some weeks before his death, he was still working on a book together with his son Olivier on problems of managing health in modern societies.

Many people around the world will remember Alain de Weck for his support and kindness. His colleagues and friends will always honor his memory and keep it alive!

Werner Pichler, Bern Johannes Ring, Munich
Obituary 